\title{
Identifying sources of dissolved organic carbon in agriculturally dominated rivers using radiocarbon age dating: Sacramento-San Joaquin River Basin, California
}

\author{
James O. Sickman • Carol L. DiGiorgio • \\ M. Lee Davisson • Delores M. Lucero • \\ Brian Bergamaschi
}

Received: 11 February 2009/Accepted: 23 October 2009/Published online: 14 November 2009

(C) The Author(s) 2009. This article is published with open access at Springerlink.com

\begin{abstract}
We used radiocarbon measurements of dissolved organic carbon (DOC) to resolve sources of riverine carbon within agriculturally dominated landscapes in California. During 2003 and 2004, average $\Delta{ }^{14} \mathrm{C}$ for DOC was $-254 \%$ in agricultural drains in the Sacramento-San Joaquin Delta, $-218 \%$ in the San Joaquin River, $-175 \%$ in the California State Water Project and $-152 \%$ in the Sacramento River.
\end{abstract}

Electronic supplementary material The online version of this article (doi:10.1007/s10533-009-9391-z) contains supplementary material, which is available to authorized users.

J. O. Sickman $(\bowtie) \cdot$ D. M. Lucero

Department of Environmental Sciences, University

of California, Riverside, CA 92521, USA

e-mail: jsickman@ucr.edu

D. M. Lucero

e-mail: dlucero@ucr.edu

C. L. DiGiorgio

Office of Water Quality, California State Department of Water Resources, Sacramento, CA 95814, USA

e-mail: caroldi@water.ca.gov

M. Lee Davisson

Lawrence Livermore National Laboratory, Livermore,

CA 94550, USA

e-mail: davisson2@1lnl.gov

B. Bergamaschi

United States Geological Survey, Sacramento, CA, USA

e-mail: bbergama@usgs.gov
The age of bulk DOC transiting the rivers of California's Central Valley is the oldest reported for large rivers and suggests wide-spread loss of soil organic matter caused by agriculture and urbanization. Using DAX 8 adsorbent, we isolated and measured ${ }^{14} \mathrm{C}$ concentrations in hydrophobic acid fractions (HPOA); river samples showed evidence of bomb-pulse carbon with average $\Delta^{14} \mathrm{C}$ of 91 and $76 \%$ for the San Joaquin and Sacramento Rivers, respectively, with older HPOA, -204\%o, observed in agricultural drains. An operationally defined nonHPOA fraction of DOC was observed in the San Joaquin River with seasonally computed $\Delta^{14} \mathrm{C}$ values of between -275 and $-687 \%$; the source of this aged material was hypothesized to be physically protected organic-matter in high clay-content soils and agrochemicals (i.e., radiocarbon-dead material) applied to farmlands. Mixing models suggest that the Sacramento River contributes about $50 \%$ of the DOC load in the California State Water Project, and agricultural drains contribute approximately one-third of the load. In contrast to studies showing stabilization of soil carbon pools within one or two decades following land conversion, sustained loss of soil organic matter, occurring many decades after the initial agricultural-land conversion, was observed in California's Central Valley.

Keywords Rivers - Dissolved organic carbon . Radiocarbon - Sacramento-San Joaquin Delta . XAD resins 


\section{Introduction}

Rivers transport the products of rock weathering and terrestrial biogenic materials to the ocean, thereby regulating atmospheric $\mathrm{CO}_{2}$ and $\mathrm{O}_{2}$ concentrations and delivering bioavailable forms of carbon to marine ecosystems (Schlesinger and Melack 1981). Stallard (1998) estimated that total riverine flux of $\mathrm{C}$ to the oceans is 0.82 petagrams $(\mathrm{Pg})$ year $^{-1}$ with the majority of the carbon transported as dissolved and particulate organic matter. The estimated organic matter flux in the World's rivers, $0.53 \mathrm{Pg} \mathrm{C}_{\text {year }}{ }^{-1}$, is approximately equal to two-thirds of annual terrestrial net ecosystem production (NEP; $0.8 \mathrm{Pg}$ C year $^{-1}$; Xiao et al. 1998).

Increasing concentrations of carbon have been detected in many rivers worldwide and have been attributed to changes in terrestrial carbon balance caused by several factors including: climate change (Freeman et al. 2001: DOC increase; Raymond and Cole 2003: alkalinity increase), $\mathrm{CO}_{2}$ fertilization of terrestrial primary productivity (Freeman et al. 2004: DOC increase), landuse change (Raymond et al. 2008: DIC increase), atmospheric deposition of nitrogen (Findlay 2005: DOC increase) and soil recovery from acid deposition (Monteith et al. 2007: DOC increase). While conversion of natural ecosystems to agricultural production systems is known to reduce soil organic carbon (Paustian et al. 1997; Smith et al. 2001), few studies have specifically assessed how this conversion has impacted DOC loads in large rivers.

Over the past 150 years the landscape of California's Central Valley has changed from chaparral, grasslands and bordering oak riparian forests to an agricultural landscape experiencing rapid urbanization. In the Sacramento-San Joaquin Delta of California (Delta), conversion of native wetlands to agriculture has led to the loss of several meters of Histosol soils with most of the loss derived from in situ microbial respiration of soil organic matter $(\sim 99 \%)$ and the remainder producing dissolved organic carbon $(\sim 1 \%)$ (Deverel and Rojstaczer 1996). Soil carbon losses are significant not only from the perspective of soil quality and atmospheric $\mathrm{CO}_{2}$ levels, but also from a human health perspective, given that DOC forms harmful disinfection byproducts upon chlorination (Bergamaschi et al. 2008); and from the perspective of aquatic ecosystem function owing to the critical role DOC plays in estuarine foodweb dynamics (Stepanauskas et al. 2002). The California State Water Project (California Aqueduct, Fig. 1) delivers municipal water exports from the Delta and supplies more than 25 million Californians with drinking water and there is a critical need to understand the sources of DOC and hence, disinfection byproducts in these waters. The Delta is largest wetlands on the west coast of the United States and is the focus of a long-term multi-million dollar restoration effort. Sources of riverine organic matter represent a significant unknown in this restoration effort (CALFED Bay-Delta Program 2008).

Given the multiple contributors of natural organic material to the Delta system, and a general lack of knowledge about soil carbon stability in the Central Valley, a more complete understanding of DOC sources, cycling and fate is needed to understand the impacts of landuse on regional carbon balance, drinking water quality and ecosystem restoration activities. Strong gradients in organic matter age are found in California's Central Valley; soil carbon may be hundreds to thousands of years old, while carbon recently fixed by algae or crops will have radiocarbon concentrations above the 1950 background level (i.e., bomb-pulse labeled). Thus we hypothesize that radiocarbon provides a means for separating sources of $\mathrm{C}$ to the DOC loads in the rivers and estuaries of agriculturally dominated landscapes.

In our study, we sought to answer two questions regarding DOC sources: (1) Does the DOC carried by the two largest rivers of California's Central Valley derive from destabilization of soil organic matter and (2) what is the dominant source of the DOC load in municipal water exports from Delta? To answer Question 1 we combined measurements of DOC radiocarbon content with other diagnostic characteristics of DOC to qualitatively assess whether soilderived carbon is major contributor to riverine DOC loads. To answer Question 2 we combined measurements of DOC concentration and radiocarbon content with a hydrologic model of the Delta, to test whether DOC contributions to the California State Water Project can be modeled as a conservative mixture of internal sources (Delta agricultural drainage) and riverine inputs (Sacramento and San Joaquin Rivers). Modeling was conducted using both total DOC and the hydrophobic organic acid fraction (HPOA) which may be primarily derived from humic substances. 
Fig. 1 Map of California (inset), the Sacramento-San Joaquin Delta and sampling sites used in the study

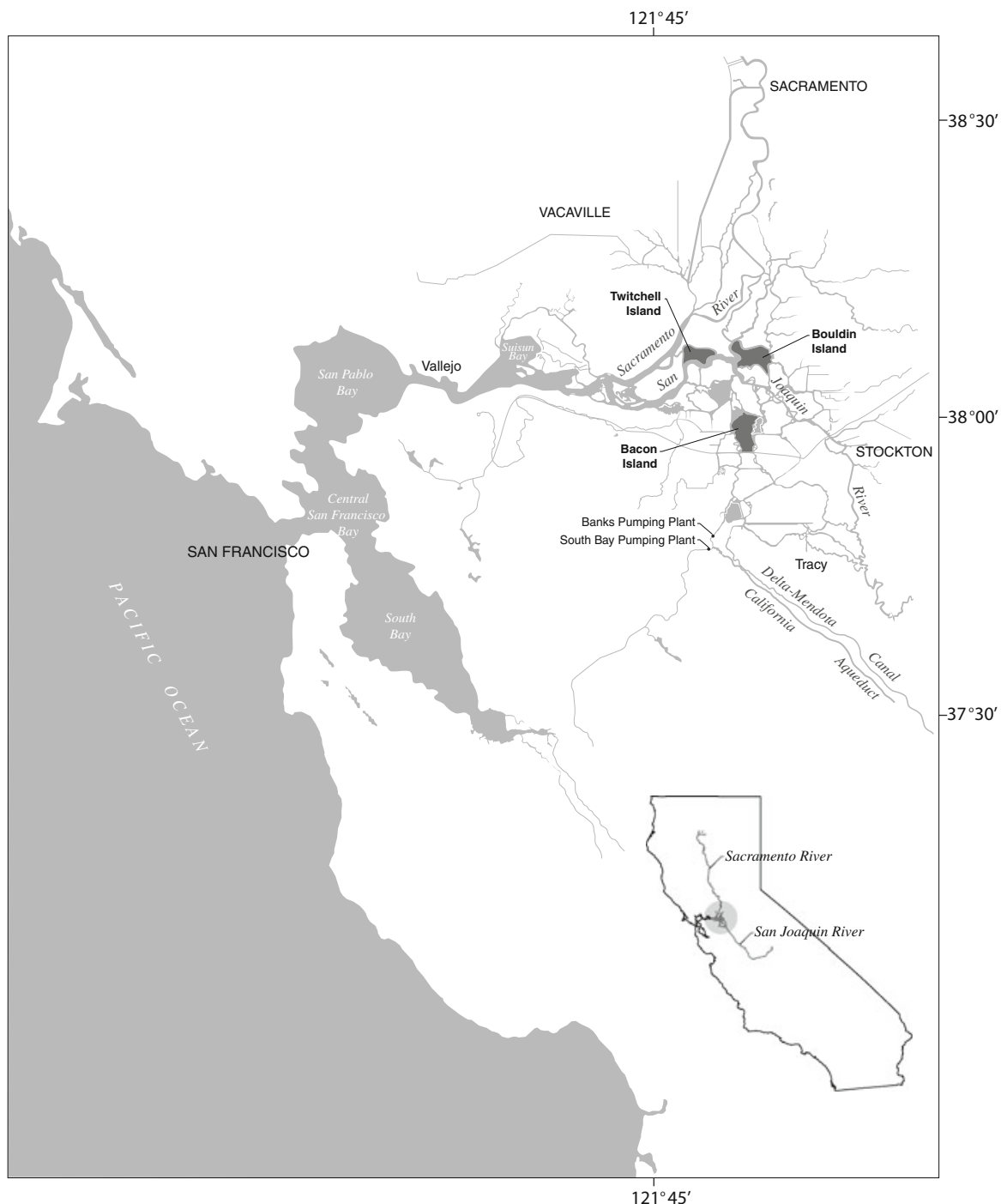

Agriculture represents one of the most important drivers of global environmental change particularly with respect to the global carbon cycle. In this manuscript we describe the likely impact of agriculture on the DOC load of two major rivers and their common estuary. Given the wide-spread distribution of agriculturally dominated rivers, particularly in Europe and Asia, our study has relevance to understanding long-term changes in riverine DOC loads caused by global change. Furthermore it confirms the growing utility of radiocarbon as a multi-scalar tracer of the carbon cycle both, qualitatively and quantitatively when combined with mass-flux models to simulate isotope-fluxes (i.e., isoflux). Lastly our study provides critically needed information about DOC sources to the Delta and California State Water Project in the context of ecosystem restoration and drinking water quality.

\section{Methods}

Surface water sampling and chemical analysis

Surface water samples were collected approximately monthly (April 2003-March 2004), within the Sacramento-San Joaquin Delta, for isolation of DOC for radiocarbon analysis and for other chemical analyses. The Delta sampling sites were: Sacramento River at Hood Station, San Joaquin River at Vernalis, State 
Water Project at the H.O. Banks Pumping Plant, and agricultural drains on Twitchell, Bouldin and Bacon Islands (Fig. 1). Samples were also collected from small tributaries carrying runoff from the Sierra Nevada in the Kaweah River drainage of Sequoia National Park during April 2005. Since both the Sacramento and San Joaquin Rivers are fed by Sierra Nevada runoff, the tributary samples provided an estimate of boundary conditions for major rivers in the Central Valley of California and were needed in our isotopic mixing models.

We also made radiocarbon measurements on DOC isolates prepared by the U.S. Geological Survey in 2000-2001 with Amberlite XAD 8 and XAD 4 resins and methods of Aiken et al. (1992). A functionally similar resin, Supelite DAX 8 was used for the 20032004 Delta samples (see Supplementary Materials). The 2000-2001 samples included the Sacramento and San Joaquin Rivers, the Twitchell Island agricultural drain and the Clifton Court Forebay to the SWP. The 2000-2001 samples were included in our study because many previous investigations have used XAD 8 and XAD 4 to collect DOC and we wanted to verify whether DAX 8, XAD 8 and XAD 4 resins collect DOC of similar radiocarbon content.

The 2003-2004 and 2005 isotope samples were collected in precombusted $\left(3 \mathrm{~h}\right.$ at $\left.500^{\circ} \mathrm{C}\right), 41$ amber glass bottles using a peristaltic pump, Teflon-lined tubing and Pall-Gelman groundwater cartridges $(0.45 \mu \mathrm{m})$. Procedural blanks were collected on each sampling date and showed no evidence of DOC contamination. At the same time three, $40 \mathrm{ml}$ amber vials (I-Chem VOA) were filled with filtered water for chemical characterization of the DOC. One of the vials was acidified to $\mathrm{pH} 2$ with $\mathrm{HCl}$ and the DOC concentration measured on a Shimadzu TOC 5000A analyzer (high temperature combustion: EPA Method 415.1). The detection limit of the analyzer was $0.25 \mathrm{mg} \mathrm{l}^{-1}$ and precision of duplicate samples was better $\pm 15 \%$. Using an unacidified duplicate, we measured absorbance of light at $254 \mathrm{~nm}$ in a $1 \mathrm{~cm}$ quartz cuvette and divided absorbance by DOC concentration in $\mathrm{mg} \mathrm{l}^{-1}$ and multiplied by 100 to yield mass-specific UV absorbance (SUVA) (Standard Methods 5910B). With the last subsample we measured dose-based, mass specific, total trihalomethane formation potential (STHMFP) using a method developed by the California Department of
Water Resources (Chow et al. 2006; STHMFP not measured for Sierra Nevada samples).

Preparation of DOC isolates

For samples collected during 2003 and 2004, we isolated and analyzed whole water DOC (WW), and hydrophobic organic acids (HPOA; Leenheer 1981). Whole water DOC was operationally defined as organic carbon that passed through a $0.45 \mu \mathrm{m}$ PallGelman groundwater filter cartridge and contains both dissolved organic carbon and colloidal organic matter. Aiken et al. (1992) defines the HPOA fraction as organic matter containing aromatic and aliphatic carboxylic acids of five to nine carbons, one- and two-ring phenols, and aquatic humic substances. These compounds supplement microbial foodwebs, attenuate light in the water column and are involved in the complexion of trace metals (Wetzel 2001). Note that we also isolated a transphilic organic acid (TPIA) fraction using XAD-4 resin, but recoveries were less than $10-15 \%$ of the total DOC loaded. The TPIA fraction is believed to be functionally similar to the HPOA fraction and contains organic acids with fewer than five $\mathrm{C}$ atoms. Because our isolation approach used relatively small collection volumes $(<51)$, the high ratio of inorganic salt to organic matter in the TPIA isolates prevented reliable $\Delta^{14} \mathrm{C}$ analysis and quantitative estimates of TPIA mass, so no data are reported.

To prepare WW isolates, we acidified the water samples to $\mathrm{pH} 2$ with trace metal grade $\mathrm{HCl}$ and used rotary evaporation alone (in vacuo at $40^{\circ} \mathrm{C}$ ) or rotary evaporation combined with lyophilization to produce a powder. For HPOA isolates, a duplicate filtered and acidified sample was loaded onto a column filled with the polymeric adsorbent, DAX 8 (lot numbers XAD8-201 and XAD-8-4004; Supelco, Bellefonte, PA) and eluted with $0.1 \mathrm{~N} \mathrm{NaOH}$ following the procedures of Aiken et al. (1992) (see Supplementary Materials). The eluates were acidified to $\mathrm{pH} 2$ with $\mathrm{HCl}$ and evaporated as above to a powder.

The mass of DOC collected as the HPOA fraction typically represented from 45 to $55 \%$ of the total DOC of agricultural drain samples and $45-60 \%$ of total DOC of river and SWP samples. Using the mass of organic carbon loaded onto the DAX 8 resin and the mass of HPOA collected, we computed the mass 
of non-recovered organic carbon for each sample. The unrecovered organic carbon was denoted nonhydrophobic organic acid (non-HPOA) and was composed of organic compounds that were irreversibly sorbed by the DAX 8 resin ( 8 and $14 \%$ of nonHPOA for river and drain samples, respectively) or that passed through the resin column unadsorbed (92 and $86 \%$ of non-HPOA for river and drain samples, respectively). Based on previous studies, the nonHPOA fraction of natural organic matter is believed to consist of hydrophilic and transphilic acids and bases and colloidal materials composed of bacterial cell wall components (i.e., $\mathrm{N}$-acetyl polysaccharides; Leenheer et al. (2004)). Knowing the mass of the non-HPOA fraction we were able to compute, by mass balance, its isotopic composition from measurements of the mass and isotopic composition of the whole water (WW) and HPOA fractions:

$\Delta_{\mathrm{non}-\mathrm{HPOA}}=\frac{m_{\mathrm{WW}} \cdot \Delta_{\mathrm{WW}}-m_{\mathrm{HPOA}} \cdot \Delta_{\mathrm{HPOA}}}{m_{\mathrm{non}-\mathrm{HPOA}}}$

where $m$ mass of organic carbon; $\Delta$ isotopic composition and the subscripts denote the three operational classes of organic matter.

Isotope analyses

All WW and HPOA isolates were analyzed for radiocarbon content. Samples were combusted in evacuated quartz tubes with $\mathrm{CuO}$ and the resultant $\mathrm{CO}_{2}$ was purified and isolated cryogenically on a vacuum extraction line. All glassware and reagents were combusted at $500^{\circ} \mathrm{C}$ prior to use. The $\mathrm{CO}_{2}$ samples were then reduced to graphite at high temperature in the presence of $\mathrm{H}_{2}$ and formed into graphite targets for ${ }^{14} \mathrm{C}$ measurement by accelerator mass spectrometry (Vogel et al. 1987). Graphitization and radiocarbon analysis were performed at the Center for Accelerator Mass Spectrometry at Lawrence Livermore National Laboratory. Radiocarbon concentrations are reported in $\Delta^{14} \mathrm{C}$ units relative to the NIST Oxalic Acid I standard and corrected to a $\delta^{13} \mathrm{C}$ value of $-25 \%$ (Stuiver and Polach 1977).

The laboratories where water samples were processed underwent regular swipe tests to monitor background ${ }^{14} \mathrm{C}$ levels and potassium hydrogen phthalate blanks were run routinely and showed no evidence for significant ${ }^{14} \mathrm{C}$ contamination (mean $\Delta{ }^{14} \mathrm{C}$ value $\left.=-996 \pm 0.5 \% ; n=10\right)$. Under basic conditions, the DAX 8 resin bled a small amount of organic carbon and a procedure was developed to correct for the effect of the bleed on the radiocarbon analyses (see Supplementary Materials).

Precision of radiocarbon analyses depended on errors from both instrumentation and sample processing and are reported as average relative standard deviation (\%RSD) of duplicate samples. Values for HPOA $\Delta{ }^{14} \mathrm{C}$ were subject to errors in radiocarbon analysis and error introduced by resin bleed correction. Cumulative errors in non-HPOA $\Delta^{14} \mathrm{C}$ depended upon all of the component errors derived from Eq. 1. Assuming independence of component variances and using standard propagation of error techniques

Table 1 Summary of expected errors in WW $\Delta^{14} \mathrm{C}$, HPOA $\Delta{ }^{14} \mathrm{C}$ and non-HPOA $\Delta^{14} \mathrm{C}$ including individual component errors

\begin{tabular}{ll}
\hline Component & $\%$ Error \\
\hline 1. Mass: WW DOC & \\
Agricultural drains & 10 \\
Rivers and SWP & 15
\end{tabular}

2. Mass: HPOA DOC

Agricultural drains $\quad 10$

Rivers and SWP $\quad 15$

3. Mass: non-HPOA DOC

Agricultural drains 14

Rivers and SWP $\quad 21$

4. Resin bleed

Agricultural drains $\quad 5.5$

Rivers and SWP 18

5. $\Delta^{14} \mathrm{C}$ : whole water

Agricultural drains $\quad 9.3$

Rivers and SWP $\quad 9.3$

6. $\Delta^{14} \mathrm{C}$ : HPOA

Agricultural drains $\quad 11$

Rivers and SWP $\quad 20$

7. $\Delta^{14} \mathrm{C}$ : non-HPOA

Agricultural drains $\quad 25$

Rivers and SWP

37

Fraction HPOA error was computed as the sum of errors from WW DOC and HPOA DOC mass errors. Resin bleed error was estimated from the average percentage contribution of bleed present in the HPOA $\Delta{ }^{14} \mathrm{C}$ samples. Total WW $\Delta{ }^{14} \mathrm{C}$ error represents sample collection, processing and analytical errors. Total HPOA $\Delta^{14} \mathrm{C}$ error represents sample collection, processing analytical errors plus resin bleed error. Total nonHPOA $\Delta{ }^{14} \mathrm{C}$ error represents propagated errors from Components 1, 2, 3, 5 and 6 (see Eq. 1) 
(Taylor 1990), we estimated the total error for all radiocarbon measurements (Table 1). Total uncertainty in WW, HPOA and non-HPOA $\Delta{ }^{14} \mathrm{C}$ estimates for agricultural drain samples were $9.3,11$ and $25 \%$, respectively. Owing to greater uncertainty in DOC concentrations and the larger impact of resin bleed, total uncertainty in WW, HPOA and non-HPOA $\Delta^{14} \mathrm{C}$ estimates for rivers and SWP samples were higher than for the drains: 9.3, 20 and 37\%, respectively.

The WW and HPOA isolates from April to August 2003 were also analyzed for $\delta^{13} \mathrm{C}$. Low variability in the $\delta^{13} \mathrm{C}$ of the samples led us to abandon these measurements after August 2003. Stable isotope analyses were performed on a Delta-Plus XP isotope ratio mass spectrometer using an elemental analyzer inlet system and continuous flow of He. Standard sucrose from the International Atomic Energy Association was included in each run. Isotope abundances are reported in $\delta$ notation relative to the standard PeeDee Belemnite.

Hydrologic and isotopic mixing models

Delta simulation model II (DSM2) is a river, estuary, and land modeling system, that was developed to simulate riverine systems within the Delta (California Department of Water Resources 2002). A volumefingerprinting technique, developed within DSM2 (Supplementary Materials), was used to determine water volume contributions at the intake to the SWP for each month between April 2003 and March 2004 and combined with water quality and isotope measurements to observe the behavior of DOC in the Delta. The model is based upon the assumption that the concentration of a conservative tracer can be estimated by summing the fractional contribution of each water source multiplied by the concentration of the tracer associated with that source:

$C_{\mathrm{cc}}=\sum_{i=1}^{N} f_{i} C_{i}$

where $C_{\mathrm{cc}}$ concentration of tracer at a specified location; $C_{i}$ tracer concentration from source $i$ at the specified location; $N$ total number of sources; and $f_{i}$ fraction of water volume at the specified location contributed by source $i$.

Five sources were used in the fingerprinting runs: Sacramento River (including the Yolo Bypass),
San Joaquin River, central Delta agricultural drains, other Delta agricultural drains, and Sierra Nevada runoff carried in the Cosumnes and Mokelumne Rivers. To investigate whether DOC concentrations (WW and HPOA DOC) at the SWP intake could be modeled as a conservative mixture of the five sources we used a mixing model based on Eq. 2 and ran it at a monthly time step. For the mixing models employing isotopic and chemical characteristics of WW and HPOA DOC $\left(\Delta^{14} \mathrm{C}\right.$, SUVA and STHMFP), DOC mass was incorporated in the model using Eq. 3:

$X_{\mathrm{SWP}}=\frac{\sum_{i=1}^{5} f_{i} \cdot C_{i} \cdot X_{i}}{C_{\mathrm{SWP}}}$

where $C_{\mathrm{SWP}}=\mathrm{DOC}$ or HPOA concentration at the SWP intake, $f_{i}=$ fractional volume contribution for source $i$ from volume fingerprinting, $C_{i}=\mathrm{DOC}$ or HPOA concentration for source $i, X_{\mathrm{SWP}}=\Delta^{14} \mathrm{C}$, SUVA or STHMFP at the SWP intake, $X_{i}=\Delta^{14} \mathrm{C}$, SUVA or STHMFP for source $i$. Modeling with Eq. 3 was conducted at a monthly time step. Missing data in Table SM-2 were interpolated (see Supplementary Materials).

To compliment the DSM2 mixing model we employed an alternative isotope-mixing model known as Isosource. Isosource (Phillips and Gregg 2003) was used to determines DOC source contributions based on stable isotope and chemical composition when sources of unknown mass were considered (e.g., DOC supplied by primary producers). Under these conditions a unique mixing solution cannot be reached so, instead, Isosource calculates ranges of possible contributions to a mixture to satisfy isotopic mass balance in the mixing model.

\section{Results}

Chemical and isotopic composition of DOC fractions

For presentation, monthly chemical and isotopic characteristics of DOC (see Auxiliary Materials, Table 1) were averaged for the following defined seasons: spring (April-June), summer (July-September), fall (October-December) and winter (JanuaryMarch). Aggregation of the data also allowed for statistical testing of differences among sites and was 
more appropriate for examining intra-annual patterns given the approximately 28 day residence time of the Delta (Jassby and Cloern 2000).

A
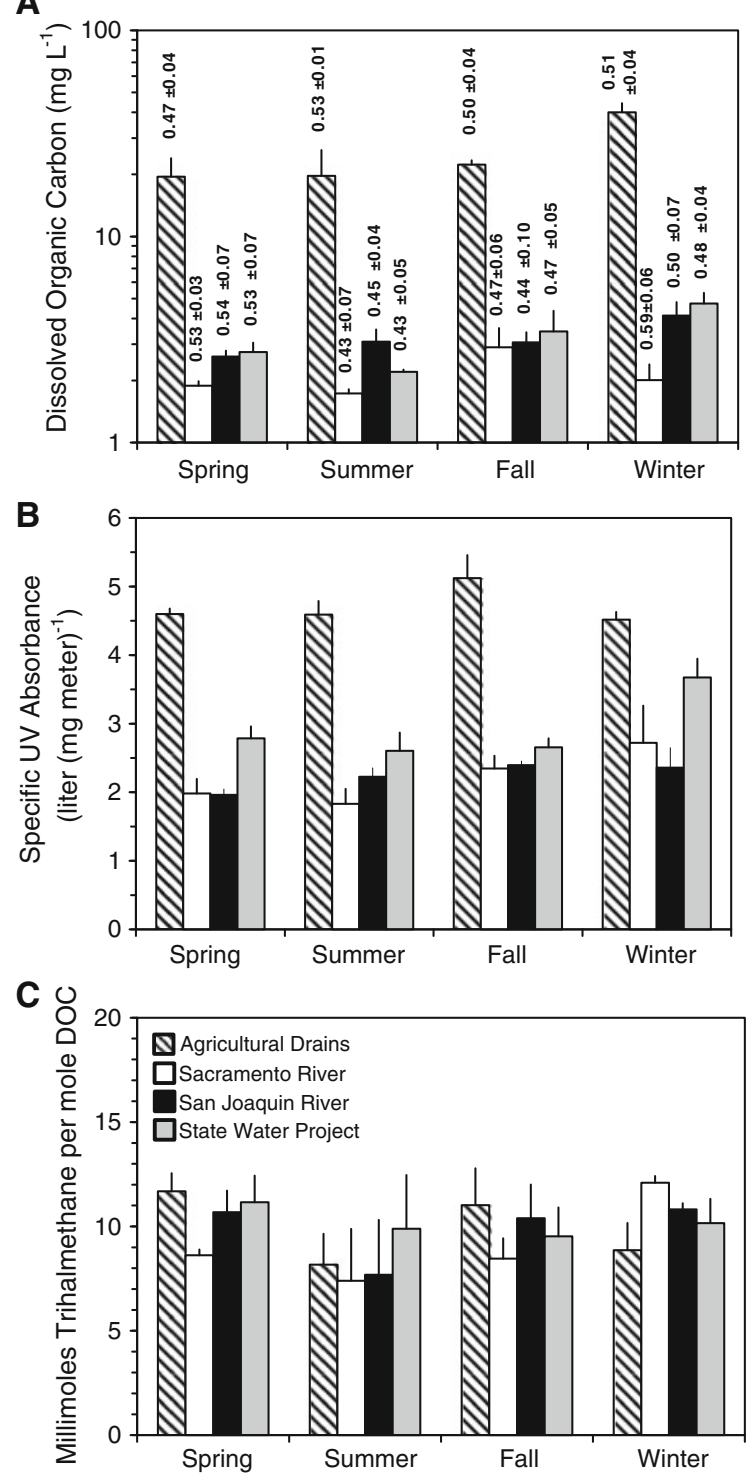

Fig. 2 Chemical characteristics of dissolved organic carbon (DOC) in Delta samples collected in 2003 and 2004. a Average DOC concentration by season and sampling site. Inset numbers $( \pm \mathrm{SE})$ are the average ratio of hydrophobic organic acid to whole water DOC mass. b Mass-specific UV 254 absorbance (SUVA) by season and sampling site. c Mass-specific trihalomethane formation potential (STHMFP) by season and sampling site
With the exception of the Sacramento River, the highest DOC concentrations were generally found during the winter (Fig. 2a). In agricultural drains, mean DOC concentrations ranged from $19.5 \mathrm{mg} \mathrm{l}^{-1}$ during spring to $40 \mathrm{mg}^{-1}$ in winter (Fig. 2a) and was 6 to 8 -fold higher than concentrations in the river samples or the SWP (range of means, 1.9-4.7 $\mathrm{mg} \mathrm{l}^{-1}$ ). The mean ratios of HPOA to WW DOC in drains ranged between 0.47 and 0.53 (inset numbers in Fig. 2a) and was not significantly different from the mean HPOA:DOC ratios in the river and SWP samples (range: 0.43-0.54). Overall, HPOA typically comprised about half of the DOC which is similar to results from other studies conducted with XAD 8 resins in the Delta (Kraus et al. 2008; Bergamaschi et al. 2000; Fujii et al. 1998). Mean specific UVA values ranged from 4.4 to $5.01\left(\mathrm{mg} \mathrm{m}^{-1}\right.$ in the drains and were $2.3-3.31$ $(\mathrm{mg} \mathrm{m})^{-1}$ in the river samples and SWP (Fig. 2b). Differences in DOC concentration and SUVA between drains and rivers are similar to earlier observations reported by Bergamaschi et al. (2000).

For the 2003-2004 samples, there were no significant differences in trihalomethane formation potential per mole (STHMFP) among the sample types for the overall data set, although significant differences were noted among samples types for specific seasons, e.g., drains had higher STHMFP than the Sacramento River during the Spring (Fig. 2c). Mean drain values ranged from 9.8 to $11.7 \mathrm{mmol}$ THM per mole DOC and mean river and SWP values ranged from 8.6 to $12.1 \mathrm{mmol}$ THM per mole DOC.

In the overall data set, WW radiocarbon concentrations for the 2003-2004 samples were significantly lower in the agricultural drains compared to all other sites $(p=0.009)$, however, ANOVAs run for individual seasons yielded no significant differences among the four sample types. Seasonal WW- $\Delta{ }^{14} \mathrm{C}$ ranged from -229 to $-284 \%$ in agricultural drains, -65 to $-220 \%$ in the Sacramento River, -192 to $-254 \%$ in the San Joaquin River and from -92 to $-260 \%$ in the SWP (Fig. 3a).

The radiocarbon content of the 2003-2004 HPOA fractions generally declined moving from spring into the summer and into the fall (Fig. 3b). ANOVA performed for the entire dataset indicated significantly lower HPOA $\Delta^{14} \mathrm{C}$ values in the agricultural samples relative to both rivers $(p<0.001)$, however there was no statistical differences between the 

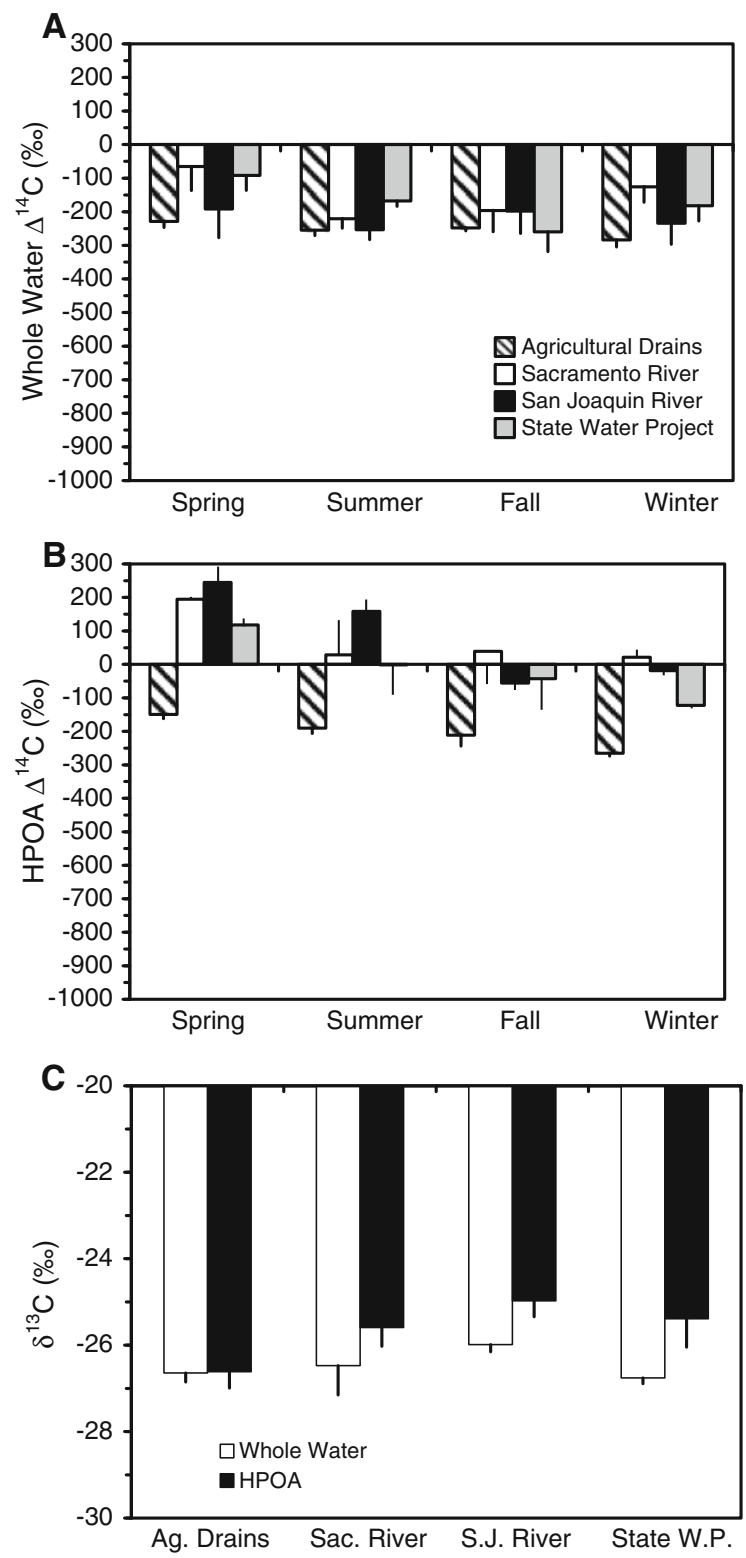

Fig. 3 Radiocarbon concentrations in DOC fractions of Delta samples collected between 2003 and 2004. a Average whole water $\Delta^{14} \mathrm{C}$ by season and sampling site. b Average hydrophobic organic acid (HPOA) $\Delta^{14} \mathrm{C}$ by season and sampling site. c Average whole water and hydrophobic organic acid (HPOA) $\delta^{13} \mathrm{C}$ by sampling site

HPOA values in the agricultural drains and the SWP. Seasonal HPOA $\Delta{ }^{14} \mathrm{C}$ ranged from -150 to $-265 \%$ o in agricultural drains, +195 to $+21 \%$ in the Sacramento River, +245 to $-19 \%$ in the San Joaquin River and +118 to $-122 \%$ in the SWP (Fig. $3 b$ ).
The stable carbon isotope composition of DOC varied less than $3 \%$ both among sites and among the DOC fractions for a single site (Fig. 3c). Average $( \pm \mathrm{SE}) \quad \delta^{13} \mathrm{C}$ of WW DOC were $-26.6 \pm 0.2$, $-26.5 \pm 0.7,-26.0 \pm 0.2$ and $-26.8 \pm 0.1 \%$ for agricultural drains, the Sacramento River, the San Joaquin River and the SWP, respectively.

Values of $\Delta^{14} \mathrm{C}$ in WW and HPOA fractions of DOC in the Delta samples from 2000 to 2001 were similar to those from 2003 to 2004 with the exception of the 19-Jul-2000 sample from the Sacramento River with unusually high, and therefore, suspect values for WW and HPOA $\Delta^{14} \mathrm{C}$ (Table 2). Whole water and HPOA $\Delta^{14} \mathrm{C}$ ranged from -54 to $-386 \%$ in agricultural drain water. All of the HPOA isolates and some of the WW isolates from the Sacramento and San Joaquin Rivers showed clear evidence for bomb-pulse carbon with values ranging from +16 to $+437 \%$. In addition to HPOA, transphilic acids (TPIA) were co-collected for some of these samples; overall the TPIA $\Delta{ }^{14} \mathrm{C}$ values closely matched the radiocarbon content of the HPOA (Fig. 4a).

Samples of WW DOC were collected during spring snowmelt in the Kaweah River drainage within Sequoia National Park in order to characterize the radiocarbon content of organic matter produced from undisturbed landscapes (Table 2). With the exception of Wall Spring, WW- $\Delta{ }^{14} \mathrm{C}$ was less than modern and ranged from -58 to $-171 \%$.

The mass and radiocarbon content of the WW and HPOA fraction were used with Eq. 1 to estimate the non-HPOA $\Delta^{14} \mathrm{C}$ values by sample type for each season. For all of the 2003-2004 samples at each site, the non-HPOA fraction had significantly lower $\Delta^{14} \mathrm{C}$ values $(p<0.001)$ than either the WW or HPOA fractions. Seasonal non-HPOA $\Delta{ }^{14} \mathrm{C}$ values ranged from -282 to $-354 \%$ in agricultural drains with an uncertainty of $\pm 25 \%$. Seasonal non-HPOA $\Delta{ }^{14} \mathrm{C}$ ranged from, -230 to $-437 \%$ in the Sacramento River, -275 to $-687 \%$ in the San Joaquin River and -258 to $-479 \%$ in the SWP. In the river and SWP samples, computation of non-HPOA $\Delta^{14} \mathrm{C}$ was complicated by low DOC concentrations and greater influence of resin bleed thus uncertainty of nonHPOA $\Delta{ }^{14} \mathrm{C}$ measurements is $\pm 37 \%$. Based on ANOVA run for the entire data set, there were no significant differences in non-HPOA $\Delta{ }^{14} \mathrm{C}$ among the four samples types or within any season. 
Table 2 Additional radiocarbon measurements of dissolved organic carbon made in the Central Valley of California and in the Kaweah River basin of the Sierra Nevada

\begin{tabular}{|c|c|c|c|c|}
\hline Site & Date & $\mathrm{WW}-\Delta^{14} \mathrm{C} \%$ & $\begin{array}{l}\text { Raw HPOA } \\
\Delta^{14} \mathrm{C} \% \text { o }\end{array}$ & $\begin{array}{l}\text { Raw TPIA } \\
\Delta^{14} \mathrm{C} \% \text { o }\end{array}$ \\
\hline \multicolumn{5}{|l|}{ Central Valley } \\
\hline \multirow[t]{2}{*}{ Twitchell Island (Agricultural drain) } & 21-Jul-2000 & -54 & -124 & -99 \\
\hline & 8-Feb-2001 & -206 & -175 & -168 \\
\hline \multirow[t]{2}{*}{ Sacramento River (Hood Station) } & 19-Jul-2000 & 383 & 437 & - \\
\hline & 5-Feb-2001 & - & 181 & - \\
\hline San Joaquin River (Mandeville Island) & 18-Jul-2000 & 26 & 123 & - \\
\hline \multirow[t]{2}{*}{ San Joaquin River (Prisoners Point) } & 20-Jul-2000 & -33 & 207 & - \\
\hline & 8-Feb-2001 & 180 & 132 & 114 \\
\hline \multirow[t]{2}{*}{ San Joaquin River (Vernalis Station) } & 16-Jul-2000 & -54 & 62 & 74 \\
\hline & 4-Feb-2001 & -364 & 39 & 58 \\
\hline \multirow[t]{2}{*}{ State Water Project (Clifton Court Forebay) } & 16-Jul-2000 & -28 & 193 & 177 \\
\hline & 4-Feb-2001 & 41 & 16 & 2 \\
\hline \multicolumn{5}{|l|}{ Kaweah River Basin } \\
\hline Marble Fork of Kaweah (Subalpine zone) & 3-Apr-2005 & -107 & - & - \\
\hline Wall Spring_Giant Forest (Mixed conifer zone) & 3-Apr-2005 & 2 & - & - \\
\hline Elk Creek (Chaparral zone) & 3-Apr-2005 & -171 & - & - \\
\hline Horse Creek (Foothill grassland zone) & 4-Apr-2005 & -58 & - & - \\
\hline
\end{tabular}

Central Valley data are from collections of DOC made with XAD 8 (HPOA DOC-fraction) and XAD 4 (TPIA DOC-fraction) resins. HPOA and TPIA radiocarbon values are not corrected for resin bleed

Relationships among isotopic and chemical characteristics of DOC

There were statistically significant correlations among the $\Delta^{14} \mathrm{C}$ of WW, HPOA and TPIA DOC (corrected and uncorrected for resin bleed) for individual Delta samples collected during 2003-2004 and 2000-2001 (Fig. 4a, b). For the bleed-corrected and WW samples collected during 2003-2004, the Pearson $r$ was 0.47 $(p<0.001)$; for samples collected with XAD 8 resin during 2000-2001, the Pearson $r$ between the HPOA and WW fractions was $0.69(p=0.026)$. Wilcoxon signed rank tests demonstrated that WW- $\Delta^{14} \mathrm{C}$ was significantly lower than bleed-corrected HPOA $\Delta^{14} \mathrm{C}$ for the 2003-2004 $(p<0.001)$ and 2000-2001 samples $(p=0.059)$. There was a strong linear correlation $\left(r^{2}=0.99\right)$ between the $\Delta^{14} \mathrm{C}$ of HPOA and TPIA DOC in the 2000-2001 samples and paired t-testing indicated no significant difference $(p=0.81)$ between the $\Delta^{14} \mathrm{C}$ of these DOC fractions.

No significant relationships were detected between the $\Delta^{14} \mathrm{C}$ or $\delta^{13} \mathrm{C}$ (not shown) of WW DOC and measures of the mass-specific UV absorbance and disinfection byproduct formation potential in individual samples when agricultural samples were separated from riverine and SWP samples (Fig. 4c). However, when all samples were combined there was a significant, negative correlation between SUVA and WW- $\Delta{ }^{14} \mathrm{C}$, i.e., older DOC had greater aromaticity (Pearson $r=-0.32 ; \quad p=0.009$ ). Interestingly, despite a range of more than $400 \%$ in $\Delta^{14} \mathrm{C}$ of WW DOC (corresponding to an age range of $>3700$ radiocarbon years), formation potential was predominantly between 9 and $12 \mathrm{mmol}$ THM per mole C.

Hydrologic and isotope mixing models

Using the volume fingerprinting algorithm within the DSM2 model we computed the fractional contribution of water at the intake to the SWP on a daily timestep between 1-Apr-2003 and 31-Mar-2004 (Fig. 5a). With the exception of a short period near the beginning of June 2003, the Sacramento River contributed greater than $50 \%$ of the water at the SWP intake; for the study period the median fraction was 0.78 . The next highest contributor to flow at the 
Fig. 4 a Radiocarbon composition of hydrophobic organic acid (HPOA) versus transphilic organic acid (TPIA) fractions for Delta DOC samples collected during 2000-2001.

b Relationship among whole water and HPOA $\Delta{ }^{14} \mathrm{C}$ for samples collected in 2003-2004 (DAX 8 polymeric resin) and 2000-2001 (XAD 8 resin). For the 2003-2004 samples both bleed-corrected and uncorrected data are presented. c Relationship between whole water DOC $\Delta{ }^{14} \mathrm{C}$ and chemical characteristics of DOC for Delta samples collected in 2003-2004
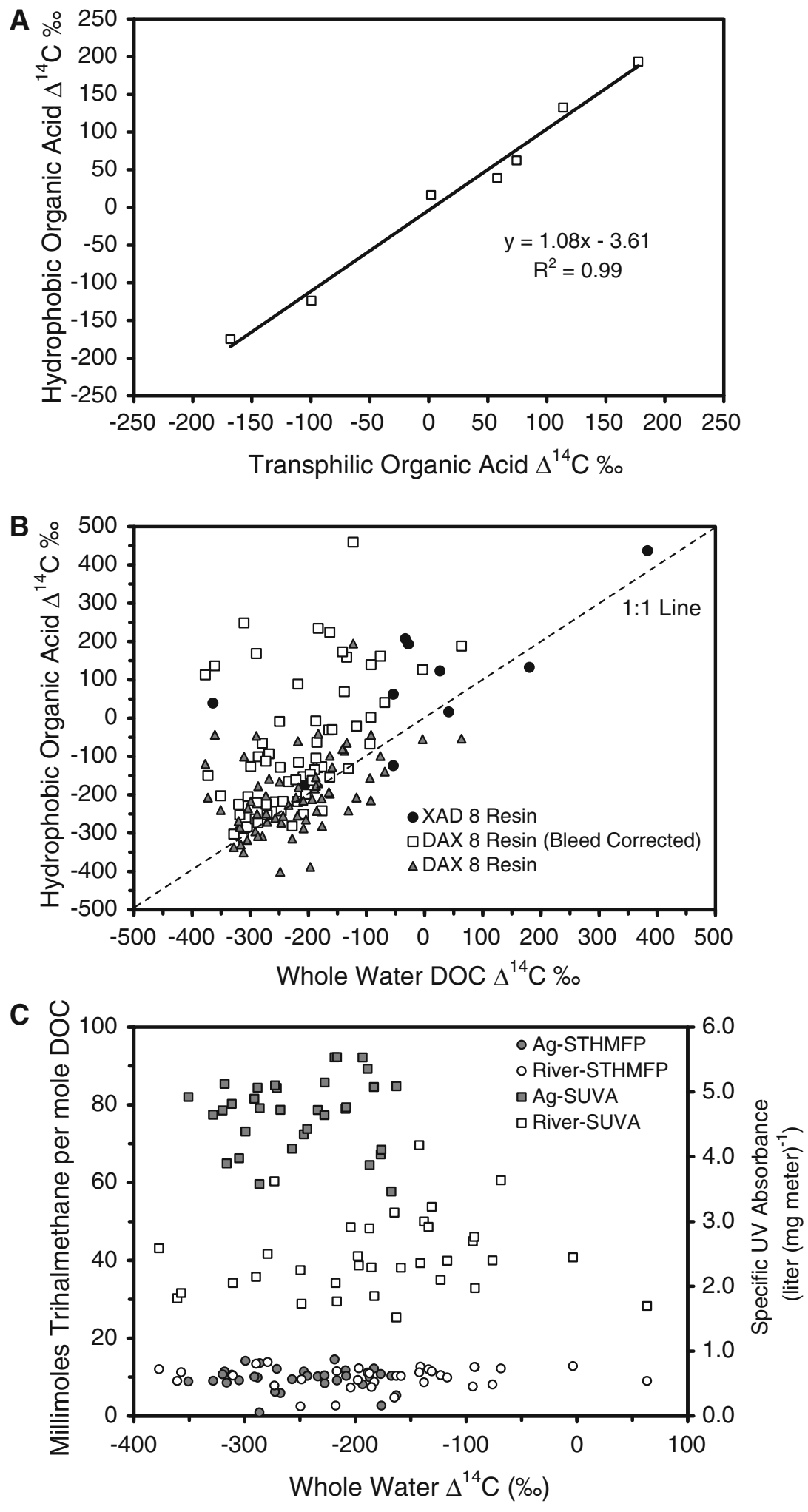

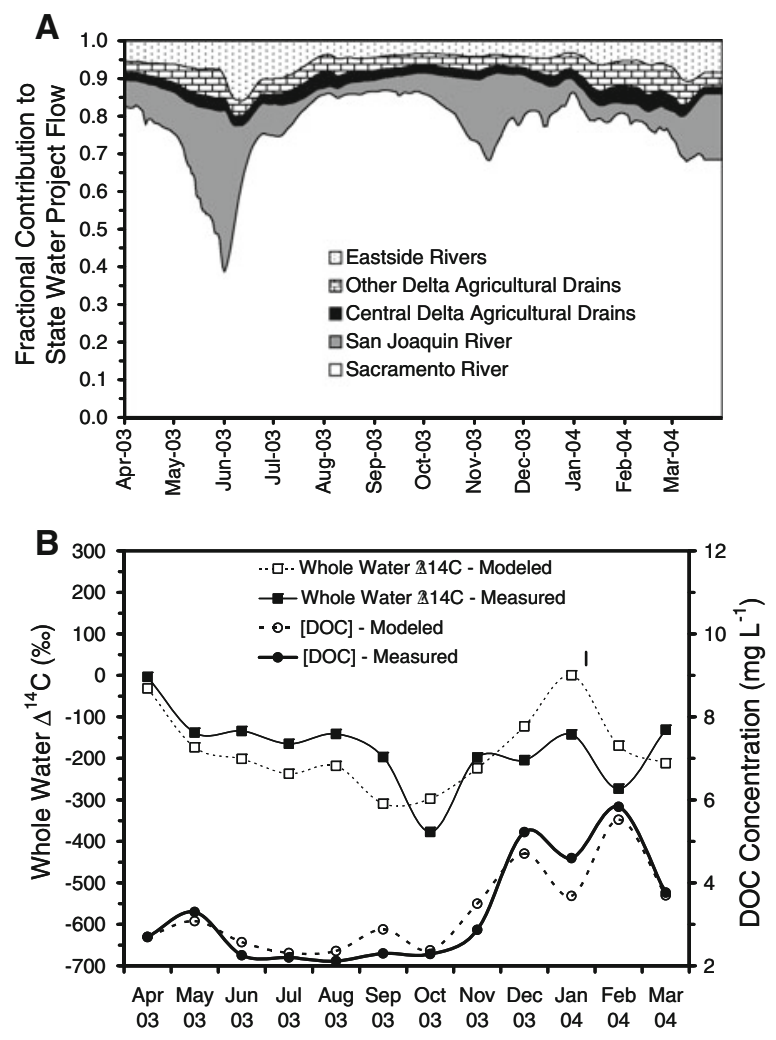

Fig. 5 a Fractional volume contributions of water sources to the intake of the State Water Project during 2003-2004 computed using the DSM2 model. b Results from conservative mixing of DOC concentration and whole water $\Delta^{14} \mathrm{C}$. Model output is compared to actual DOC concentrations and whole

SWP intake was the San Joaquin River (median $=0.077$, range: $0.018-0.429$ ), followed by the Cosumnes and Mokelumne rivers which drain into the eastern portion of the Delta from the Sierra Nevada (median $=0.053$, range: $0.031-0.131$ ), agricultural drains outside of the central Delta (median $=0.041$, range: $0.028-0.078$ ) and central Delta agricultural drains (median $=0.025$, range: 0.018-0.046).

The fractional contributions of water for each source were averaged for individual months and then combined with DOC, HPOA and radiocarbon concentrations (WW and HPOA), and SUVA and STHMFP using Eqs. 2 and 3 to test the hypothesis that DOC concentration and chemical/isotopic composition at the SWP intake can be predicted from conservative mixing of water sources (Fig. 5b-d). The model produced good agreement with measured DOC concentration and trends, with an adjusted $r^{2}$
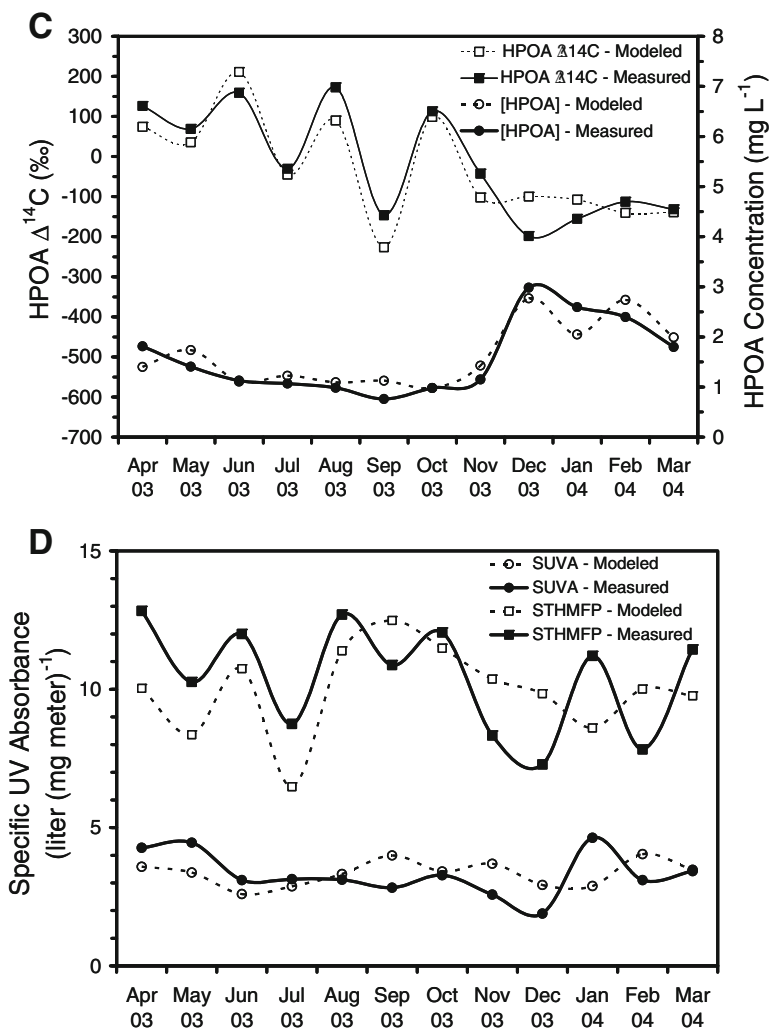

water $\Delta^{14} \mathrm{C}$ measured at the intake of the State Water Project. c Results from conservative mixing of HPOA concentration and HPOA- $-{ }^{14}$ C. d Results from conservative mixing of SUVA concentration and STHMFP_State Water Project

value of 0.91 . However, the slope of the regression line, 1.23 ( $x=$ modeled, $y=$ measured for all regressions), was significantly different from 1 and indicated the model under-predicted DOC concentrations at the SWP intake (Fig. 5b).

Modeled WW- $\Delta{ }^{14} \mathrm{C}$ closely matched measured $\Delta^{14} \mathrm{C}$ in only three of twelve months (adjusted $r^{2}=0.32$ ), however, the model did capture upward and downward trends in $\mathrm{WW}-\Delta{ }^{14} \mathrm{C}$ values (Fig. 5b). There was strong bias in the model during two periods: June through September when measured $\mathrm{WW}-\Delta^{14} \mathrm{C}$ was higher (younger) than predicted and December through February when measured WW$\Delta{ }^{14} \mathrm{C}$ was lower (older) than predicted. For the months of August and December, we used interpolated values for WW- $\Delta{ }^{14} \mathrm{C}$ in the San Joaquin River, since these samples were lost. However, since the fractional contribution of water from the San Joaquin River for these months was 2.8 and $7.8 \%$, 
respectively, we believe that interpolation had little effect on the modeling results.

The mixing model for HPOA concentration and HPOA $\Delta{ }^{14} \mathrm{C}$ were successful in predicting conditions at the SWP intake (Fig. 5c). Differences between measured and modeled HPOA were typically less than $0.5 \mathrm{mg} \mathrm{C}^{-1}$ in all months and exhibited no bias; the adjusted $r^{2}$ value was 0.83 and the slope of the regression was 1.06 and not significantly different from 1. Modeled HPOA- $\Delta{ }^{14} \mathrm{C}$ closely followed month-to-month changes in HPOA- $\Delta{ }^{14} \mathrm{C}$ at the SWP intake (Fig. 5c). The only periods when significant biases were observed were: (a) August and September where modeled HPOA- $\Delta{ }^{14} \mathrm{C}$ was lower than measured HPOA- $\Delta^{14} \mathrm{C}$ and (b) December and January where modeled HPOA- $\Delta{ }^{14} \mathrm{C}$ was higher than measured values. These biases in HPOA were consistent with $\mathrm{WW}-\Delta^{14} \mathrm{C}$ biases. The adjusted $r^{2}$ between measured and modeled HPOA- $\Delta{ }^{14} \mathrm{C}$ was 0.83 and the slope of the regression 0.96 , was not significantly different from.

In contrast to DOC and radiocarbon concentrations, mixing models incorporating mass-specific UV absorbance and THMFP performed poorly. The models generally failed to capture the month-tomonth patterns observed at the SWP intake (Fig. 5d) and regressions between modeled and measured SUVA and STHMFP yielded non-significant slopes and low $r^{2}$ values. The models also produced several periods of substantial bias for both parameters.

\section{Discussion}

Sources of riverine DOC in agriculturally dominated rivers

At the points where the Sacramento and San Joaquin Rivers enter the Delta, WW DOC $\Delta^{14} \mathrm{C}$ averaged -152 and $-218 \%$, respectively, which corresponds to mean ages of approximately 1,250 to 1,900 radiocarbon years (Table 3 ). The average $\Delta^{14} \mathrm{C}$ of WW DOC in Delta agricultural drainage was slightly lower, $-254 \%$ (ca. 2,300 radiocarbon years) suggesting that the majority of riverine DOC delivered to the Delta is derived from soils within the Sacramento and San Joaquin Valleys. Similarly, Stern et al. (2007) reported average $\Delta^{14} \mathrm{C}$ of $-198 \%$ for DOC collected in artificial wetlands in the northern
Everglades agricultural region and concluded that peat soils were the primary source of this old organic matter (Table 3). However, for other river DOC where $\Delta^{14} \mathrm{C}$ has been measured and is unrelated to wetlands, such low $\Delta^{14} \mathrm{C}$ has not been observed. For example, in the Amazon River, Mayorga et al. (2005) reported $\Delta^{14} \mathrm{C}$ concentrations of +94 to $+196 \%$ in WW DOC with similarly aged DOC $(+82$ to $+210 \%$ ) observed in rivers of the eastern United States by Raymond and Bauer (2001) and Raymond et al. (2004). Somewhat older WW DOC was measured in rivers draining into the Arctic Ocean $(+5$ to $+78 \%$ o) by Striegl et al. (2007) and in runoff from peatlands in the United Kingdom reported by Evans et al. (2007) ( -63 to $+66 \%$ ).

It is instructive to compare the flux of DOC carried in the Central Valley rivers to estimates of soil carbon losses (Table 4). Eve et al. (2002) used the Century Model (Parton et al. 1988) to estimate both soil carbon storage and the annual change in organic carbon in agricultural soils of the U.S. (Table 4). Using these data we estimate that soils within the Central Valley contain 160 teragrams of organic carbon in the top meter and 0.34 teragrams are being lost per year, yielding an average residence time of 470 years assuming carbon losses are primarily confined to the top meter of soil. The fact that mean $\mathrm{WW}-\Delta^{14} \mathrm{C}$ in the major Central Valley rivers is on the order of 1,250-1,900 years shows that old soil carbon is being destabilized, most likely by human activity. The ratio of annual soil organic carbon loss to annual DOC load in the Sacramento and San Joaquin Rivers (0.075 teragrams C) is $4.5: 1$, suggesting that soil carbon losses are dominated by microbial respiration of $\mathrm{CO}_{2}$.

The average $\Delta^{14} \mathrm{C}$ of the HPOA fraction $(+76$ to $+91 \%$ ) in the Sacramento and San Joaquin rivers are similar to those reported in other rivers and lakes (e.g., Hedges et al. 1986; Abbott and Stafford 1996; Leenheer et al. 2004). More importantly, HPOA$\Delta{ }^{14} \mathrm{C}$ values were higher than the WW- $\Delta{ }^{14} \mathrm{C}$ and, consequently, the $\Delta^{14} \mathrm{C}$ of the non-HPOA computed from Eq. 1 consistently yielded significantly lower non-HPOA $\Delta^{14} \mathrm{C}$ values, especially for the San Joaquin River where seasonal averages ranged from -275 to $-687 \%$. Most samples of the Sacramento and San Joaquin Rivers had WW and non-HPOA $\Delta{ }^{14} \mathrm{C}$ values significantly lower than $\mathrm{WW}-\Delta{ }^{14} \mathrm{C}$ measured in undisturbed areas of the upper Sierra 
Table 3 Radiocarbon measurements of DOC in streams and rivers world-wide

\begin{tabular}{|c|c|c|c|}
\hline Region & $\begin{array}{l}\text { Citation } \\
\text { location }\end{array}$ & Whole-water $\Delta^{14} \mathrm{C} \%$ & HPOA $\Delta \Delta^{14} \mathrm{C} \%$ \\
\hline \multirow[t]{4}{*}{ Amazon Basin } & \multicolumn{3}{|l|}{ Mayorga et al. (2005) } \\
\hline & Mountain & $94 \pm 176$ & \\
\hline & Mixed & $196 \pm 59$ & \\
\hline & Lowlands & $177 \pm 64$ & \\
\hline \multirow[t]{10}{*}{ Arctic } & \multicolumn{3}{|l|}{ Raymond et al. (2007) } \\
\hline & Lena River & $78 \pm 25$ & \\
\hline & Ob’ River & $14 \pm 51$ & \\
\hline & Yenisey River & $62 \pm 47$ & \\
\hline & Yukon River & $5 \pm 53$ & \\
\hline & Mackenzie River & $7 \pm 35$ & \\
\hline & \multicolumn{3}{|l|}{ Striegl et al. (2007) } \\
\hline & Porcupine River & 63 & \\
\hline & Tanana River & -36 & \\
\hline & Yukon River & -56 & \\
\hline \multirow[t]{8}{*}{ United Kingdom } & \multicolumn{3}{|l|}{ Evans et al. (2007) } \\
\hline & *Peat Moorland & $37 \pm 5$ & \\
\hline & *Peaty Gley & $66 \pm 10$ & \\
\hline & *Montane Grassland & $-63 \pm 124$ & \\
\hline & *Improved Grassland & $-53 \pm 30$ & \\
\hline & $*$ Conifer Forest & $38 \pm 31$ & \\
\hline & *Mixed Catchments & $22 \pm 20$ & \\
\hline & \multicolumn{3}{|l|}{ (*Low Flow Periods only) } \\
\hline \multirow[t]{2}{*}{ Baffin Island, Canada } & \multicolumn{3}{|l|}{ Abbott and Stafford (1996) } \\
\hline & Lake Water & & $60 \pm 59$ \\
\hline \multirow[t]{5}{*}{ Eastern United States } & \multicolumn{3}{|c|}{ Raymond et al. (2004) and Raymond and Bauer (2001) } \\
\hline & Hudson & $89 \pm 77$ & \\
\hline & York & $210 \pm 40$ & \\
\hline & Parker & $82 \pm 48$ & \\
\hline & Delaware & $145 \pm 149$ & \\
\hline \multirow[t]{2}{*}{ Everglades, Florida } & \multicolumn{3}{|l|}{ Stern et al. (2007) } \\
\hline & Stormwater Treatment Area & $-198 \pm 28$ & \\
\hline \multirow[t]{5}{*}{ Interior California } & \multicolumn{3}{|l|}{ This study } \\
\hline & San Joaquin River & $-218 \pm 99$ & $91 \pm 159$ \\
\hline & Sacramento River & $-152 \pm 103$ & $76 \pm 139$ \\
\hline & Agricultural Runoff & $-254 \pm 32$ & $-204 \pm 52$ \\
\hline & State Water Project & $-175 \pm 90$ & $2 \pm 142$ \\
\hline
\end{tabular}

Mean values are reported \pm standard deviation where replicate measurements were available

Nevada watershed, indicating older DOC is added to rivers as they pass through regions of intensive agricultural production.

Low WW- $\Delta{ }^{14} \mathrm{C}$ values are ubiquitous in the Sacramento and San Joaquin rivers and in general appear to be related to disturbance of soils by agricultural activities and urbanization (Sickman et al. 2007). In contrast, it is not straightforward to conclude a soil source of especially old, non-HPOA. Ewing et al. (2006) investigated the effects of soil structure and soil disruption on the $\Delta^{14} \mathrm{C}$ of soil organic carbon and concluded that soil structures 
Table 4 Comparison of organic carbon pools and riverine loads in the Central Valley of California

\begin{tabular}{ll}
\hline Organic C pool/load & Teragrams C \\
\hline Soil organic carbon in top meter of soil ${ }^{\mathrm{a}}$ & 160 \\
Annual loss of soil organic carbon & 0.34 \\
Annual DOC load in the Sacramento and San Joaquin Rivers $^{\mathrm{b}}$ & 0.075 \\
Non-HPOA load in the Sacramento and San Joaquin Rivers & \\
Agrochemical application (active ingredient) $^{\mathrm{d}}$ & 0.037 \\
\hline
\end{tabular}

Estimates of annual soil organic carbon losses are from Eve et al. (2002)

a Assumes an average organic carbon content of $1.5 \mathrm{~kg} \mathrm{~m}^{-2}$ and land area of $109,000 \mathrm{~km}^{2}$

b Average of wet and dry year loads from Tetra Tech Inc. (2006)

c Value assumes that $50 \%$ of total DOC is non-HPOA

d Based on average application rate of $1,000 \mathrm{~kg} \mathrm{~km}^{-2}$ active ingredient, land area of 109,000 $\mathrm{km}^{2}$ and assumption that active ingredient is $80 \%$ carbon by weight

(peds) in San Joaquin Valley soils offer physical protection to soil organic carbon over millennial time scales even when the organic matter is not biochemically recalcitrant. During incubation studies of intact grassland and orchard soils with high clay content, Ewing et al. found that disruption of the peds produced $\mathrm{CO}_{2}$ that was considerably more depleted in ${ }^{14} \mathrm{C}$ than the bulk soil; in one experiment, the $\Delta{ }^{14} \mathrm{C}$ of $\mathrm{CO}_{2}$ produced from $\mathrm{B}$ horizon orchard soils ranged between -716 to $-908 \%$. Implicit in the biodegradation of old soil carbon is the incorporation of aged carbon in microbial cell mass. In this case, the growth and decay cycles of the microbial mass could contribute to the DOC pool as well, adding saccharide and amino compounds from lyzed cells that have an apparently old age. Evidence for abundance of these compounds in colloidal hydrophilic fractions in terrestrial and marine water DOC is increasing (Guo and Santschi 1997; Leenheer et al. 2004; Kawasaki and Benner 2006; Jorgensen et al. 2008). This source of organic matter would be consistent with the hydrophilic fraction of DOC in the Sacramento and San Joaquin rivers, and its apparently old age a result of the intense cultivation and subsequent biodegradation of previously occluded but now exposed soil organic matter. This source of old hydrophilic DOC would also explain the distinct apparent age difference between the HPOA and the non-HPOA fractions.

The aged non-HPOA measured in our study may also be ${ }^{14} \mathrm{C}$-depleted materials derived from petroleum; examples include agrochemical active ingredient and oil-based carriers and/or their decomposition products. Other sources of fossil carbon include oils in non-point urban runoff, treated sewage containing synthetic detergents and polyacrylamide which is commonly used to control soil erosion both on farms and construction sites. Interestingly, black carbon from fossil fuel combustion has also been detected in large rivers (Mitra et al. 2002) and evidence is growing that $\mathrm{BC}$ is an important component of the global carbon cycle (Mannino and Harvey 2004).

The possibility that fossil carbon might contribute to DOC loads in rivers was first proposed by Spiker and Rubin (1975). Using a simple isotope mixing model, they estimated that fossil carbon contributed as much as $20-30 \%$ of the total DOC load in several rivers along the U.S. east coast. However, their mixing model did not take into account that DOC derived from soils could be hundreds to thousands of years old, thus their model overestimated the true contribution of oil-based chemicals in these rivers.

Estimating the mass of agrochemical carbon applied to land in the Central Valley is complicated by the large number of compounds used and lack of data on petroleum carriers employed during the field application process. Based on data collected from the California Department of Pesticide Regulation and summarized by the Pesticide Action Network (Kegley et al. 2008), we estimate that 0.087 teragrams of carbon are applied as pesticide active ingredient in the Central Valley and that total carbon applications are likely several times greater (Table 4). Agrochemical carbon application roughly equals the total DOC load in the Sacramento and San Joaquin Rivers, however more research is needed to understand the chemical and physical transformations necessary to solubilize and transport these compounds to rivers. 
Trends in DOC loads in agriculturally dominated rivers

Trends in the carbon loads of major rivers are indicators of changes in regional carbon balance caused by global environmental change. Observed ground subsidence within the Sacramento-San Joaquin Delta (Mount and Twiss 2005) demonstrates widespread loss of soil organic matter, but investigations of water quality trends in the Central Valley provide no evidence for increasing riverine DOC concentrations between 1980 and 2000 (Saleh et al. 2003). We speculate, however, that a longer of record of DOC concentrations extending to the early twentieth century would show increases in the San Joaquin and Sacramento Rivers given results from our radiocarbon study and data on radiocarbon dating of DOC in other rivers.

Worrall and Burt (2007) reported that DOC concentrations increased at 216 out of 315 river monitoring stations in Great Britain between 1975 and 2002 and radiocarbon analysis of DOC in these rivers point to complex source mechanisms for increasing DOC concentrations. Evans et al. (2007) found that rivers in the United Kingdom (UK), carrying runoff from undisturbed peatlands, had DOC composed primarily of carbon fixed during the past 50 years. This finding suggests that DOC in the Delta and Central Valley rivers, prior to agricultural reclamation, was much younger than today. Radiocarbon measurements made by Evans et al., in rivers draining intensively managed farmlands had average $\Delta^{14} \mathrm{C}$ of ca. $-60 \%$ o $(\sim 500$ radiocarbon years) indicating soil carbon destabilization caused by agriculture, although the degree of soil organic matter loss is more modest than that occurring in the Central Valley of California. Further radiocarbon measurements by Billett et al. (2007) in other UK peatlands revealed that, while the riverine DOC pool consisted primarily of bomb-labeled C, the DIC pool was derived from a more ${ }^{14} \mathrm{C}$-depleted source (older soil organic matter or carbonate minerals) with mean age of 500 to 1,500 radiocarbon years $\left(\Delta^{14} \mathrm{C}\right.$-DIC was not measured in our study). While agricultural practices and perhaps urbanization explain increasing trends in DOC concentration from disturbed landscapes in the UK, some other mechanism, such as decreased sulfur deposition and recovery of soils from acid rain, may be causing destabilization of soil carbon pools in non-agricultural UK lands.
DOC loading to the State Water Project

Recent studies using both mass balance (Jassby and Cloern 2000; Tetra Tech Inc. 2006) and DOC fingerprinting (Kraus et al. 2008) techniques have found that riverine inputs are the dominant source of DOC to the Delta on an annual basis. Our mixing models based on isotopic and chemical fingerprints of DOC and HPOA (Eq. 3) show that organic matter may undergo substantial chemical transformations (as evidenced by poor modeling of SUVA and STHMFP) and the overall organic matter pool maybe turning over (as evidenced by biases in WW and HPOA$\Delta^{14} \mathrm{C}$ ) as river water moves through the Delta. This finding increases the uncertainty in estimates of monthly DOC and HPOA contributions to the SWP intake, particularly in periods of the year when the fingerprinting models show substantial bias (e.g., summer and winter months in Fig. 5b, c). Nevertheless, source contributions may be estimated with reasonable accuracy on an annual basis if one assumes that: (a) poor SUVA and STHMFP model performance arose from chemical changes rather than unaccounted for inputs or losses of DOC, (b) errors arising from turnover of the DOC pool compensate over the course of a year and (c) DSM2 volume fractions are accurate. With these assumptions, our mixing models suggest that $33 \%$ of the annual WW and HPOA DOC load in the SWP is contributed by Delta agricultural drainage and $66 \%$ is contributed by riverine input. By itself we estimate that the Sacramento River contributes $50 \%$ of the annual WW and HPOA DOC load in the SWP. Given, the relatively narrow range of STHMFP values measured in our study, DBP precursor source proportions should be similar (Fig. 4c).

The WW- $\Delta{ }^{14} \mathrm{C}$ model consistently predicted older carbon than was observed at the SWP intake during the late spring and summer, and it predicted younger carbon than was observed at the SWP intake during December through February when river discharge was highest. In this latter case, we hypothesize that the DSM2 model underestimated winter-time pumping from agricultural drains resulting in underestimation of WW DOC concentration and overestimation of WW- and HPOA- $\Delta{ }^{14} \mathrm{C}$ (Fig. 5b). In contrast, since the DSM2 model produced relatively good fits between predicted and modeled WW and HPOA DOC concentrations for the growing season, we hypothesize 
that the spring/summer bias in our WW- $\Delta{ }^{14} \mathrm{C}$ models derived from replacement of older riverine DOC with younger DOC from primary production (i.e., turnover of the DOC pool) during the summer. This hypothesis is supported by mass balance studies which show increasing contributions of wetland DOC during the spring and summer growing season (Fleck et al. 2007). Moreover, the average WW- $\Delta{ }^{14} \mathrm{C}$ at the SWP during the summer fell above (i.e., was younger than) the range of $\mathrm{WW}-\Delta^{14} \mathrm{C}$ for any of the measured sources (Fig. 3a), thus there must have been a younger source of Delta DOC contributing to SWP DOC loads. Using the alternative mixing model, Isosource and three potential end members (average summer WW- $\Delta{ }^{14} \mathrm{C}$ values for agricultural drains $(-255 \%)$, and riverine inputs $(-237 \%$ ), along with primary productivity with $\Delta^{14} \mathrm{C}$ value of $50 \%$ o) we estimate that $17-35 \%$ of the WW DOC at the SWP intake in the months of JulySeptember 2003 was recently fixed organic matter. Kraus et al. (2008), using an independent DOC fingerprinting method, predicted that $30 \%$ and $16 \%$ of DOC in Clifton Court Forebay during May and July 2000 was contributed by recent primary production in Delta wetlands.

\section{Conclusions}

In contrast to earlier studies that examine carbon loss from ecosystems following conversion to agriculture, ours is one of the first to suggest that old carbon losses continue for decades after the conversion process is complete. Mean radiocarbon values for WW DOC in agricultural drainage, the Sacramento River, the San Joaquin River and State Water Project were: $-254 \pm 99,-152 \pm 103,-218 \pm 99$ and $-175 \pm$ $90 \%$, respectively. Hydrophobic acid (HPOA) fractions in the riverine samples were significantly younger and averaged, $-204 \pm 52,76 \pm 139,91 \pm 159$ and $2 \pm 142 \%$ for agricultural drains, Sacramento and San Joaquin River and the intake of the State Water Project, respectively. The WW DOC radiocarbon values measured in our study were older than the HPOA values; this finding held true for agricultural drain samples, and both of the major rivers in the Central Valley of California. Using mass balance, we estimated the concentration and radiocarbon content of the non-HPOA DOC fraction which fell below $-500 \%$ in some riverine samples. The source of this extremely old DOC is unknown, but we speculate that it derives from physically protected soil organic matter that is being disturbed by human activities in the Central Valley or petroleum-based compounds. Mixing modeling using radiocarbon and other chemical characteristics of DOC suggest that the Sacramento River is the single largest source of DOC to the State Water Project. Primary productivity contributes $17-35 \%$ of the DOC at the SWP intake during the growing season and loading from agricultural drain contributes about one-third of annual DOC load in the State Water Project.

Acknowledgements This study was a collaborative effort of Municipal Water Quality Investigations of the Department of Water Resources (DWR). We specifically thank DWR Field Staff, David Gonzalez, Steven San Julian, Walt Lambert and Arin Conner for assistance with water sampling. We thank the Center For Accelerator Mass Spectrometry at Lawrence Livermore National Laboratory for conducting the radiocarbon measurements. Supporting laboratory analyses were conducted by the Bryte Analytical Laboratory. Funding was provided by the CALFED Bay Delta Program and the California State Water Contractors.

Open Access This article is distributed under the terms of the Creative Commons Attribution Noncommercial License which permits any noncommercial use, distribution, and reproduction in any medium, provided the original author(s) and source are credited.

\section{References}

Abbott MB, Stafford TW (1996) Radiocarbon geochemistry of modern and ancient Arctic lake systems, Baffin Island, Canada. Quat Res 45:300-311

Aiken GR, McKnight DM, Thorn KA, Thurman EM (1992) Isolation of hydrophilic organic-acids from water using nonionic macroporous resins. Org Geochem 18:567-573

Bergamaschi BA, Fram MS, Fujii R, Aiken GR, Kendall C, Silva SR (2000) The carbon isotopic composition of trihalomethanes formed from chemically distinct dissolved organic carbon isolates from the Sacramento-San Joaquin River Delta. In: Barret SE, Krasner SW, Amy GL (eds) ACS symposium series 761: natural organic matter and disinfection by-products: characterization and control in drinking water. American Chemical Society, Washington, DC, pp 206-222

Bergamaschi B, DiGiorgio C, Fujii R, Gartell G, Harader S, Losee R, Sickman JO, Swift T (2008) Tracking organic matter in Delta drinking water. Science action: news from the CALFED Science Program. http://science.calwater. ca.gov/pdf/publications/sia/SIA_DOC_041608.pdf

Billett MF, Garnett MH, Harvey F (2007) UK peatland streams release old carbon dioxide to the atmosphere and young 
dissolved organic carbon to rivers. Geophys Res Lett 34:L23401

CALFED Bay-Delta Program (2008) Tracking organic matter in Delta drinking water, science action: news from the CALFED Science Program. California Department of Water Resources, Sacramento, CA, p 8

California Department of Water Resources (2002) An introduction to the Delta Simulation Model II (DSM2) for simulation of hydrodynamics and water quality of the Sacramento-San Joaquin Delta, Memorandum Report. California Department of Water Resources, Sacramento, California, $175 \mathrm{pp}$

Chow AT, Guo FM, Gao SD, Breuer RS (2006) Trihalomethane reactivity of water- and sodium hydroxideextractable organic carbon fractions from peat soils. J Environ Qual 35:114-121

Deverel SJ, Rojstaczer S (1996) Subsidence of agricultural lands in the Sacramento San Joaquin Delta, California: role of aqueous and gaseous carbon fluxes. Water Resour Res 32:2359-2367

Evans CD, Freeman C, Cork LG, Thomas DN, Reynolds B, Billett MF, Garnett MH, Norris D (2007) Evidence against recent climate-induced destabilisation of soil carbon from C-14 analysis of riverine dissolved organic matter. Geophys Res Lett 34:L07407

Eve MD, Sperow M, Paustian K, Follett RF (2002) Nationalscale estimation of changes in soil carbon stocks on agricultural lands. Environ Pollut 116:431-438

Ewing SA, Sanderman J, Baisden WT, Wang Y, Amundson R (2006) Role of large-scale soil structure in organic carbon turnover: evidence from California grassland soils. J Geophys Res 111:G03012

Findlay SEG (2005) Increased carbon transport in the Hudson River: unexpected consequence of nitrogen deposition? Front Ecol Environ 3:133-137

Fleck JA, Fram MS, Fujii R (2007) Organic carbon and disinfection byproduct precursor loads from a constructed, non-tidal wetland in California's Sacramento-San Joaquin Delta. San Franc Estuary Watershed Sci 5:1-24

Freeman C, Evans CD, Monteith DT, Reynolds B, Fenner N (2001) Export of organic carbon from peat soils. Nature 412:785

Freeman C, Fenner N, Ostle NJ, Kang H, Dowrick DJ, Reynolds B, Lock MA, Sleep D, Hughes S, Hudson J (2004) Export of dissolved organic carbon from peatlands under elevated carbon dioxide levels. Nature 430:195-198

Fujii R, Ranalli AJ, Aiken GR, Bergamaschi BA (1998) Dissolved organic carbon concentrations and compositions and trihalomethane formation potentials in waters from agricultural peat soils, Sacramento-San Joaquin Delta, California: implications for drinking-water quality. Water-Resources Investigations Report, 98-4147, U.S. Geological Survey

Guo LD, Santschi PH (1997) Isotopic and elemental characterization of colloidal organic matter from the Chesapeake Bay and Galveston Bay. Mar Chem 59:1-15

Hedges JI, Ertel JR, Quay PD, Grootes PM, Richey JE, Devol AH, Farwell GW, Schmidt FW, Salati E (1986) Organic C-14 in the Amazon River System. Science 231:1129-1131

Jassby AD, Cloern JE (2000) Organic matter sources and rehabilitation of the Sacramento-San Joaquin Delta
(California, USA). Aquat Conserv Mar Freshw Ecosyst 10:323-352

Jorgensen NOG, Engel P, Jellison R, Hollibaugh JT (2008) Contribution of bacterial cell wall components to DOM in alkaline, hypersaline Mono Lake, California. Geomicrobiol J 25:38-55

Kawasaki N, Benner R (2006) Bacterial release of dissolved organic matter during cell growth and decline: molecular origin and composition. Limnol Oceanogr 51:2170-2180

Kegley SE, Hill BR, Orme S, Choi AH (2008) Pesticide action network pesticides database-California Pesticide use (on line). http://www.pesticideinfo.org

Kraus TEC, Bergamaschi BA, Hernes PJ, Stepanauskas R, Kendall C, Losee RF, Fuji R (2008) Assessing the contribution of wetlands and subsided islands to dissolved organic matter and disinfection byproduct precursors in the Sacramento-San Joaquin River Delta: a geochemical approach. Org Geochem 39:1302-1318

Leenheer JA (1981) Comprehensive approach to preparative isolation and fractionation of dissolved organic-carbon from natural-waters and wastewaters. Environ Sci Technol 15:578-587

Leenheer JA, Noyes TI, Rostad CE, Davisson ML (2004) Characterization and origin of polar dissolved organic matter from the Great Salt Lake. Biogeochemistry 69: 125-141

Mannino A, Harvey RH (2004) Black carbon in estuarine and coastal ocean dissolved organic matter. Limnol Oceanogr 49:735-740

Mayorga E, Aufdenkampe AK, Masiello CA, Krusche AV, Hedges JI, Quay PD, Richey JE, Brown TA (2005) Young organic matter as a source of carbon dioxide outgassing from Amazonian rivers. Nature 436:538-541

Mitra S, Bianchi TS, McKee BA, Sutula MA (2002) Black carbon from the Mississippi River: quantities, sources, and implications for the global carbon cycle. Environ Sci Technol 36:2296-2302

Monteith DT, Stoddard JL, Evans CD, de Wit HA, Forsius M, Hogasen T, Wilander A, Skjelkvale BL, Jeffries DS, Vuorenmaa J, Keller B, Kopacek J, Vesely J (2007) Dissolved organic carbon trends resulting from changes in atmospheric deposition chemistry. Nature 450:537-539

Mount R, Twiss J (2005) Subsidence, sea level rise, seismicity in the Sacramento-San Joaquin Delta. San Franc Estuary Watershed Sci 3:1-18

Parton WJ, Stewart JWB, Cole CV (1988) Dynamics of C, N, P and $\mathrm{S}$ in Grassland Soils - a model. Biogeochemistry 5:109-131

Paustian K, Andren O, Janzen HH, Lal R, Smith P, Tian G, Tiessen H, Van Noordwijk M, Woomer PL (1997) Agricultural soils as a sink to mitigate $\mathrm{CO}_{2}$ emissions. Soil Use Manag 13:230-244

Phillips DL, Gregg JW (2003) Source partitioning using stable isotopes: coping with too many sources. Oecologia 136: 261-269

Raymond PA, Bauer JE (2001) Riverine export of aged terrestrial organic matter to the North Atlantic Ocean. Nature 409:497-500

Raymond PA, Cole JJ (2003) Increase in the export of alkalinity from North America's largest river. Science 301:88-91 
Raymond PA, Bauer JE, Caraco NF, Cole JJ, Longworth B, Petsch ST (2004) Controls on the variability of organic matter and dissolved inorganic carbon ages in northeast US rivers. Mar Chem 92:353-366

Raymond PA, McClelland JW, Holmes RM, Zhulidov AV, Mull K, Peterson BJ, Striegl RG, Aiken GR, Gurtovaya TY (2007) The flux and age of DOC exported to the Arctic Ocean: a carbon isotopic study of the five largest arctic rivers. Glob Biogeochem Cycles 21:GB4011. doi: 10.1029/2007GB002934

Raymond PA, Oh NH, Turner RE, Broussard W (2008) Anthropogenically enhanced fluxes of water and carbon from the Mississippi River. Nature 451:449-452

Saleh DK, Domagalski JL, Kratzer CR, Knifong DL (2003) Organic carbon trends, loads, and yields to the Sacramento-San Joaquin Delta, California, water years 19802000. Water-Resources Investigation Report, 03-4070, U.S. Geological Survey

Schlesinger WH, Melack JM (1981) Transport of organiccarbon in the World's rivers. Tellus 33:172-187

Sickman JO, Zanoli MJ, Mann HL (2007) Effects of urbanization on organic carbon loads in the Sacramento River, California. Water Resour Res 43:W11422. doi: 10.1029/2007WR005954

Smith SV, Renwick WH, Buddemeier RW, Crossland CJ (2001) Budgets of soil erosion and deposition for sediments and sedimentary organic carbon across the coterminous United States. Glob Biogeochem Cycles 15:697-707

Spiker EC, Rubin M (1975) Petroleum pollutants in surface and groundwater as indicated by C-14 activity of dissolved organic carbon. Science 187:61-64

Stallard RF (1998) Terrestrial sedimentation and the carbon cycle: coupling weathering and erosion to carbon burial. Glob Biogeochem Cycles 12:231-257
Stepanauskas R, Moran MA, Bergamaschi BA, Hollibaugh JT (2002) Sources, bioavailability, and photoreactivity of dissolved organic carbon in the Sacramento-San Joaquin River Delta. Biogeochemistry 74:131-149

Stern J, Wang Y, Gu B, Newman J (2007) Distribution and turnover of carbon in natural and constructed wetlands in the Florida Everglades. Appl Geochem 22:1936-1948

Striegl RG, Dornblaser MM, Aiken GR, Wickland KP, Raymond PA (2007) Carbon export and cycling by the Yukon, Tanana, and Porcupine rivers, Alaska, 2001-2005. Water Resour Res 43:W02411

Stuiver M, Polach HA (1977) Reporting of C-14 data-discussion. Radiocarbon 19:355-363

Taylor JK (1990) Statistical techniques for data analysis. A. F. Lewis, New York

Tetra Tech Inc. (2006) Conceptual model for organic carbon in the Central Valley and Sacramento-San Joaquin Delta. Central Valley Drinking Water Policy Workgroup

Vogel JS, Nelson DE, Southon JR (1987) C-14 background levels in an accelerator mass-spectrometry system. Radiocarbon 29:323-333

Wetzel RG (2001) Limnology: lake and river ecosystems, 3rd edn. Academic Press, San Diego

Worrall F, Burt TP (2007) Trends in DOC concentration in Great Britain. J Hydrol 346:81-92

Xiao X, Melillo JM, Kicklighter DW, McGuire AD, Prinn RG, Wang C, Stone PH, Sokolov A (1998) Transient climate change and net ecosystem production of the terrestrial biosphere. Glob Biogeochem Cycles 12:345-360 